\title{
ATM gene mutations in former uranium miners of SDAG Wismut: A pilot study
}

\author{
JOACHIM SCHNEIDER ${ }^{1}$, MONIKA PHILIPP ${ }^{1}$, PARIA YAMINI ${ }^{2,3}$, \\ THILO DÖRK ${ }^{3}$ and HANS-JOACHIM WOITOWITZ ${ }^{1}$ \\ ${ }^{1}$ Institut und Poliklinik für Arbeits- und Sozialmedizin, Justus-Liebig Universität, Aulweg 129/III, D-35385 Giessen; \\ ${ }^{2}$ Abteilung Strahlentherapie und spezielle Onkologie, Medizinische Hochschule Hannover, Carl-Neuberg-Str. 1, \\ D-30625 Hannover; ${ }^{3}$ Frauenklinik im Forschungszentrum, Medizinische Hochschule Hannover, \\ Carl-Neuberg-Str. 1, D-30625 Hannover, Germany
}

Received August 16, 2006; Accepted October 30, 2006

\begin{abstract}
Ataxia-telangiectasia is an autosomal recessive disease characterized by neurological and immunological symptoms, radiosensitivity and cancer predisposition. Heterozygous carriers of an ataxia-telangiectasia gene mutation are predisposed to epithelial cancers. We initiated a study to elucidate the frequency and clinical relevance of ATM gene mutations in former uranium miners exposed to high levels of radiation from radon and its decay products. Former uranium miners with Schneeberg lung cancer $(n=48)$, former uranium miners suffering from silicosis $(n=60)$ and uranium miners without occupational lung disorders $(n=102)$ were investigated for nine mutations in the ATM gene. One gastric and one prostate cancer occurred in the group of miners without occupational lung diseases. Mutation analyses for S707P, IVS10-6T $\rightarrow$ G, 2250G $\rightarrow$ A, E1978X, R2443X, 3801delG, S49C and D2625E-A2626P were performed using genomic DNA obtained from peripheral blood samples. Three ATM gene alterations (S707P, S49C or IVS10-6T $\rightarrow$ G) were observed. Of all cancer patients, $8.0 \%$ were heterozygous, but only $1.9 \%$ of the non-cancer controls were $[\mathrm{OR}=4.6 ; 95 \%$ confidence interval (CI), 0.8-26.8]. In this pilot study a major role of six ATM gene mutations could not be revealed for cancer predisposition in former uranium miners. The results leave the possibility of a moderate risk associated with more subtle ATM gene alterations.
\end{abstract}

\section{Introduction}

After World War II, in 1946, the Soviet occupation authorities started uranium mining and processing in East Germany.

Correspondence to: Dr Joachim Schneider, Institut und Poliklinik für Arbeits- und Sozialmedizin, Justus-Liebig Universität, Aulweg 129/III, D-35385 Giessen, Germany

E-mail: joachim.schneider@arbmed.med.uni-giessen.de

Key words: ATM gene, uranium miners, lung cancer
Between 1946 and 1990, the Wismut Company employed between 500,000-600,000 people, with at least half of them exposed to ionising radiation during underground mining and uranium processing. Miners who had been exposed for the first time between 1946 and 1954, the years with the poorest working conditions, showed high mean cumulative radon exposures (709 working level months) $(1,2)$. Due to unsafe working conditions, exposures were in the range of $10-100 \mathrm{mg} /$ $\mathrm{m}^{3}$ dust with high content of crystalline silica (3). Later on, working conditions were improved and exposure was reduced (1). After German reunification in 1990, uranium mines in Saxony and Thuringia were closed. At present, overall 20,000 cases of silicosis and $\sim 9,000$ cases of lung cancer were reported from this high-risk group (4,5). Of the latter, $~ 5,300$ were compensated as occupational diseases (6). Since 1995 up to 4,800 additional lung cancer cases have been predicted in the population of exposed former Wismut workers in Saxony (7). The syncarcinogenic effect of radon exposure and smoking has been demonstrated in Wismut employees (8). The carcinogenic effect of crystalline silica is also taken into consideration.

DNA lesions will be evoked followed by a period of repair, mis-repair or non-repair. Analysis of repair processes is problematic owing to the low number of lesions per unit of time that have to be repaired. The effective repair process during chronic exposure makes application of indicator systems of DNA damage very difficult. However, a previous study using the comet assay has uncovered an increase in unrepaired DNA damage in cells from former Wismut employees affected by lung cancer (9).

We would like to initiate a study to elucidate the clinical relevance of genetic susceptibility to lung cancer with regard to the role of DNA damage and repair. For a complex disease such as lung cancer, multiple genes probably act independently or interact with other genes to influence the disease phenotype. Polymorphisms could have functional relevance. Our approach is involved in the DNA repair machinery by analysing the ATM and the X-ray repair cross-complementing gene group. In this pilot study, we focused on the ataxia-telangiectasia (A-T) gene mutations (ATM) in former uranium miners of SDAG Wismut, Germany. 
Ataxia-telangiectasia (A-T) is the classic paradigm of a human genetic disease involving severe ionising radiation sensitivity which has been studied by radiation biologists over many decades $(10,11)$. A-T is an autosomal recessive disorder characterized by progressive cerebellar degeneration, oculocutanous telangiectasia, thymus dysplasia, immunodeficiency and bronchopulmonary infections, gonadal dysgenesis, chromosomal instability, abnormal X-ray sensitivity and cancer predisposition $(12,13)$. The incidence in the USA is approximately $1: 100,000$.

Cultured cells from AT patients are also hypersensitive to ionising radiation and show defective activation of radiationinduced cell cycle check-points, including retarded p53 stabilisation (14-20). Heterozygous carriers of an A-T mutation ( $\sim 1 \%$ of the population) are clinically unaffected, but there is reported evidence from epidemiological studies that A-T heterozygosity predisposes to some epithelial cancers (21-25). Cancer incidence among A-T heterozygotes has been estimated to be 3- to 4-fold higher than in the general population. It has been suggested that diagnostic exposure to ionizing radiation probably increases the risk of breast cancer in women heterozygous for ataxia-telangiectasia (26).

The gene mutated in A-T, designated the ATM gene, has been localized to chromosome 11q23 and contains 66 exons (27-29). The ATM gene encodes a large protein kinase with a PI-3 kinase-related domain. This protein is involved in DNA damage response and cell cycle regulation (11,30-35). Molecular studies have shown that ATM is upstream of p53 in a pathway that activates $a_{1}-S$ check-point. In A-T cells, there is a delay in the increase of p53 levels that follows $\gamma$ irradiation $(36,37)$. The link between the ATM and p53 gene products, and the subsequent identification of several other oncoproteins as targets of ATM $(35,38)$, supports the hypothesis of a tumor-suppressive function of ATM.

Until today numerous different mutations in the ATM gene have been identified in classical A-T patients. The majority of the published mutations in the ATM gene are truncating, although missense substitutions and in-frame deletions have also been found $(30,39-48)$. Most studies have used cDNA for analysing ATM gene mutations. After complete sequence informations are available, mutation-scanning methods using genomic DNA have been possible.

The aim of our study is the analysis of ATM gene alterations that could predispose towards radiation-induced cancer due to a constitutional dysfunction in the cellular DNA damage response pathways. In the pilot phase, we report the screening results of nine tested ATM mutations in former uranium miners.

\section{Patients and methods}

Case selection. In this project, $\mathrm{n}=48$ former uranium miners of SDAG Wismut (67.5 \pm 5.8 years; $10 \%$ actual smokers, $90 \%$ ever smokers) with lung cancer and a history of exposure towards ionising radiation (radon and its decay products) were examined [criteria for diagnosis (49)]. The lung cancer patients were recruited from the Klinik für Lungenkrankheiten und Tuberkulose in Bad Berka and the Klinik für Berufskrankheiten in Falkenstein, Germany. Histological classification of the lung carcinoma cases yielded $n=14$ adenocarcinoma $(65.7 \pm 8.0$ years $), n=29$ squamous $(67.8 \pm 8.6)$, and $\mathrm{n}=5$ large cell, mixed or non-classifiable bronchial carcinoma (65.0 \pm 12.7 years).

They were compared to $n=102$ former uranium miners of SDAG Wismut $(66.6 \pm 4.5$ years; $15 \%$ actual smokers, $80 \%$ ever smokers, $5 \%$ never smokers) without occupational lung disease (i.e., silicosis, asbestosis or chronic obstructive airway diseases). Samples were taken from a multi-center study concerning the effects of radiation-induced illness in former uranium miners of SDAG Wismut. All miners took part in the medical surveillance program by ZeBWis (Zentrale Betreuungsstelle Wismut). The health status of each subject was confirmed in a clinical examination that included X-rays. All patients underwent bronchoscopy. Cancer had occurred in two of these miners (one gastric cancer, one prostate cancer).

The uranium miners (UM) had started their work within the Wismut Company between 1946 and 1978, and over 50\% had stopped working as miners before 1980. The mean time of employment at the company was 21.8 years (range 0.4 42.1 years). Work in the underground mine was approximately 14.5 years, and exposure to ionising radiation in uranium processing was calculated at 7.4 years. Cumulative exposure in WLM (WLM, Working Level Month; one WL is the $\alpha$ - energy concentration of radon daughters in equilibrium with $100 \mathrm{pCi} / 1$ or $3,700 \mathrm{~Bq} / \mathrm{m}^{3}$ radon) was calculated in each UM by ZeBWis (Central Association of the German Statutory Accidents Insurance Institutions with its special branch for the observation of the health of former Wismut Workers). The mean exposure was calculated at $612 \pm 500$ WLMs (range 0.7-1954 WLM) or $6.4 \pm 9.76 \mathrm{kBqh} / \mathrm{m}^{3}$ (range $0.06-80 \mathrm{kBqh} / \mathrm{m}^{3}$ ) and $53.5 \pm 101.7 \mathrm{mSV}$ (range 0-874.3 $\mathrm{mSv}$ ) respectively. Individual exposure estimates for dust, arsenic or asbestos were not available.

Additionally, $\mathrm{n}=60$ former uranium miners $(72.0 \pm 2.8$ years; $11.7 \%$ actual smokers, $76.7 \%$ ever smokers, $11.7 \%$ never smokers) suffering from silicosis were included as second control group. They underwent clinical treatment at a clinic for occupational diseases to improve rehabilitation. None of the patients showed signs of malignant diseases.

Methods. Peripheral EDTA blood samples were collected. Genomic DNA was extracted from leucocytes of all persons and served as the primary source for mutational screening. Mutation analysis of the coding exons of the ATM gene was performed in the genomic DNA. Mutation analysis for S707P and IVS10-6T $\rightarrow$ G were performed as described previously (50). The screening of mutations 2250G $\rightarrow$ A, E1978X, R2443X, 3801delG, S49C and D2625E-A2626P was performed using a newly established hexaplex ARMS (amplification refractory mutation system) [(51) primer sequences available from the authors]. In brief, PCR amplifications were performed in 20- $\mu 1$ reaction volumes containing $\sim 100 \mathrm{ng}$ of genomic DNA, $0.25 \mathrm{mM}$ each dNTP and 2.5 U Taq-DNA polymerase in the reaction buffer supplied by the manufacturer (Qiagen). Primer concentrations were adjusted to allow for the simultaneous detection of six mutant or wild-type ATM fragments, respectively. As the standard procedure, 35 PCR cycles were performed with 1-min denaturation at $95^{\circ} \mathrm{C}, 1$-min annealing at 57 or $62^{\circ} \mathrm{C}$, depending on the primer pairs, and 1-min elongation at $72^{\circ} \mathrm{C}$. Electrophoresis was performed on high- 
Table I. Mutation analysis of the ATM gene in 210 former uranium miners.

\begin{tabular}{|c|c|c|c|c|}
\hline \multirow[b]{2}{*}{ Mutation } & \multirow[b]{2}{*}{ Nucleotide } & \multirow[b]{2}{*}{ Location } & \multicolumn{2}{|c|}{ Uranium miners } \\
\hline & & & No. & $(\%)$ \\
\hline \multicolumn{5}{|l|}{$\begin{array}{l}\text { Amino acid } \\
\text { mutations }\end{array}$} \\
\hline S49C & $\mathrm{C} \rightarrow \mathrm{G}$ at 146 & Exon 5 & 4 Heterozygote & 1.90 \\
\hline S707P & $\mathrm{T} \rightarrow \mathrm{C}$ at 2119 & Exon 15 & 2 Heterozygote & 0.95 \\
\hline \multirow[t]{2}{*}{ D2625E-A2626P } & $\mathrm{T} \rightarrow \mathrm{G}$ at 7875 & & & \\
\hline & $\mathrm{G} \rightarrow \mathrm{C}$ at 7876 & Exon 55 & 0 Heterozygote & 0.00 \\
\hline \multicolumn{5}{|l|}{ Splicing mutation } \\
\hline IVS10-6T $\rightarrow \mathrm{G}$ & $\mathrm{T} \rightarrow \mathrm{G}$ at $1066-6$ & Intron 10 & 1 Heterozygote & 0.48 \\
\hline $2250 \mathrm{G} \rightarrow \mathrm{A}$ & $\mathrm{G} \rightarrow \mathrm{A}$ at 2250 & Exon 16 & 0 Heterozygote & 0.00 \\
\hline \multicolumn{5}{|l|}{ Truncating mutation } \\
\hline $3801 \mathrm{delG}$ & Deletion of $G$ at $3801-3802$ & Exon 28 & 0 Heterozygote & 0.00 \\
\hline E1978X & $\mathrm{G} \rightarrow \mathrm{T}$ at 5932 & Exon 42 & 0 Heterozygote & 0.00 \\
\hline $\mathrm{R} 2443 \mathrm{X}$ & $\mathrm{C} \rightarrow \mathrm{T}$ at 7327 & Exon 52 & 0 Hetreozygote & 0.00 \\
\hline Total mutations & & & 7 Heterozygote & 3.33 \\
\hline
\end{tabular}

Mutations are designated according to the recommended nomenclature (65). Nucleotides are numbered according to the published ATM cDNA sequences (66), beginning with the first nucleotide of the start codon.

Table II. Prevalence of ATM mutations in former uranium miners.

\begin{tabular}{|c|c|c|c|c|c|c|c|c|c|}
\hline \multirow[b]{2}{*}{ Mutation } & \multicolumn{3}{|c|}{$\begin{array}{l}\text { Wismut cancer patients } \\
\qquad(\mathrm{n}=50)\end{array}$} & \multicolumn{3}{|c|}{$\begin{array}{l}\text { Wismut non-cancer controls } \\
\qquad(\mathrm{n}=160)\end{array}$} & \multirow[b]{2}{*}{ P-value ${ }^{a}$} & \multirow[b]{2}{*}{ OR } & \multirow[b]{2}{*}{$95 \% \mathrm{CI}$} \\
\hline & $\mathrm{n}$ & $(\%)$ & Diagnosis & $\mathrm{n}$ & $(\%)$ & Diagnosis & & & \\
\hline \multirow[t]{2}{*}{$\mathrm{S} 49 \mathrm{C}$} & 1 & 2.00 & Gastric cancer & 1 & 0.63 & Healthy & 0.04 & 10.2 & $0.9-259.4$ \\
\hline & 2 & 4.00 & Lung cancer & & & & $0.14^{\mathrm{b}}$ & $6.6^{\mathrm{b}}$ & $0.4-188.8^{b}$ \\
\hline S707P & 1 & 2.00 & Prostate cancer & 1 & 0.63 & Silicosis $(q / q 3 / 3 B)^{c}$ & 0.42 & 3.2 & $0.0-121.2$ \\
\hline IVS10-6T $\rightarrow \mathrm{G}$ & - & - & - & 1 & 0.63 & Silicosis $(\mathrm{p} / \mathrm{q} 3 / 2 \mathrm{~A})^{\mathrm{c}}$ & 1.00 & - & $0.0-56.3$ \\
\hline All three mutations & 4 & 8.00 & & 3 & 1.88 & & 0.04 & 4.6 & $0.8-26.8$ \\
\hline
\end{tabular}

${ }^{a}$ Fisher's exact test (2-tailed). ${ }^{\mathrm{b}}$ Analysis restricted to lung cancer. ${ }^{\mathrm{c} I L O}$ classification of radiographs for pneumoconiosis (small opacities p/q resp. q/q; profusion category 3/2 resp. 3/3, large opacities A resp. B) (67). Carrier frequencies are given as numbers of heterozygotes. Comparison between Wismut cancer patients and all non-cancer controls (healthy persons and patients suffering from silicosis).

resolution agarose gels $(2.5 \%$ NuSieve agarose, BioWhittaker) including $50 \mathrm{ng} / \mathrm{ml}$ ethidium bromide in $0.8 \mathrm{X}$ Tris-borateEDTA at $5 \mathrm{~V} / \mathrm{cm}$ at room temperature. Bands were visualized by UV light and photographed.

\section{Results}

Two hundred and ten former uranium miners were investigated for nine mutations in the ATM gene. As suspected, homozygotes for A-T mutations could not be detected. A total of 7 heterozygotes were identified (Table I).
The most frequent heterozygosity was found for the amino acid substitution S49C in four individuals (1.90\%) followed by $\mathrm{S} 707 \mathrm{P}$ in two persons $(0.95 \%)$. A truncating AT mutation, the splicing mutation IVS10-6T $\rightarrow \mathrm{G}$ within the acceptor splice site of intron 10 of the ATM gene, was only detectable in a single person from the non-cancer group $(0.48 \%)$. Other classic A-T mutations did not occur in either subgroup.

To elucidate whether the mutations predispose to cancer, the prevalence of ATM mutations were grouped into cases suffering from cancer ( $n=50$, including $n=48$ lung cancer) and controls without cancer $(n=160)$ (Table II). 
S49C or S707P are rare in the control group (0.63\%) and only seen in single persons. These substitutions were found in a higher percentage in cancer patients than in non-cancer controls (Table II). The differences were not significant for the S707P mutation. The OR of the cumulative frequencies of the S49C heterozygotes between all cancer patients and persons without cancer was elevated $(\mathrm{OR}=10.2)$. Using the Fisher's exact test this result was significant $(\mathrm{p}=0.04)$. If the analysis was restricted only to lung cancer patients, the OR remained elevated $(\mathrm{OR}=6.63)$, but the differences were not significant $(\mathrm{p}=0.14)$.

The splicing mutation IVS10-6T $\rightarrow \mathrm{G}$ has only been detected in one silicosis patient, but not in any cancer patient. Three ATM gene alterations (S707P, S49C or IVS10-6T $\rightarrow$ G) were observed. Heterozygous individuals were observed as $8.0 \%$ of all cancer patients but only $1.9 \%$ of the non-cancer controls. The calculated crude $\mathrm{OR}=4.6$ may reflect a modest cancer predisposition associated with dysfunctional ATM.

\section{Discussion}

In this pilot study we screened for ATM gene alterations in a total of 210 former uranium miners exposed to ionising radiation. More than 46 different ATM mutations and 26 sequence polymorphisms and variants were previously identified in 66 ataxia-telangiectasia patients from German families (48). Only 7 mutations occurred in more than one AT-family. In this preliminary study we focused therefore on nine selected mutations that were commonly observed either in A-T patients or in German breast cancer patients $(48,50)$.

The most frequent truncating AT mutation in breast cancer is a splicing mutation, polypyrimidine tract substitution IVS10-6T $\rightarrow$ G within the acceptor splice site of intron 10 of the ATM gene $(50,52)$. However in former uranium miners this mutation could only be found in one single patient suffering from severe silicosis. Respirable quartz dust was classified as a carcinogen. Epidemiological studies revealed an association between lung cancer and exposure to quartz dust. Metaanalysis of epidemiological studies $(53,54)$ showed high risks $(\mathrm{RR}>2.0)$ for developing lung cancer in patients suffering from silicosis. So the heterozygous silicosis patient has to be followed-up with respect to a possible development of lung cancer.

In two previous studies of breast cancer patients $(50,55)$ the S707P substitution was significantly more frequent in cases than in the general population. We did not detect this mutation in $n=100$ healthy uranium miners but ATM heterozygosity for S707P was found in one $(0.63 \%)$ patient with silicosis and in one patient with prostate cancer. How far this result can be interpreted in terms of cancer predisposition needs further investigation. In a family study of AT patients, in which the risk of cancer according to ATM heterozygosity status was estimated, prostate cancer was not significantly increased (56). Studies of workers exposed to ionising radiation usually focus on mortality in relation to the whole body exposure. The relation to neutron and surface exposure has also been examined (57). Surface exposure was significantly $(\mathrm{p}<0.001)$ related to prostate cancer. Among prostate cancer a clearly increased mortality in relation to exposure was described (58). Because other relevant information was not available, the reason for the increased mortality from prostate cancer could not be determined. Epidemiological studies failed to correlate significant excess of prostate cancer with high exposure to ionising radiation (59). However A-T heterozygous individuals have been identified among patients with prostate cancer (60). Patients carrying a significant mutation in the ATM gene are over-represented in prostate cancer that developed serious late responses to high-dose external-beam conformal radiation therapy (60).

The most prominent trend was observed for the S49C amino acid substitution in exon 5 of the ATM gene. Three of the $n=50$ cancer patients but only one of the $n=160$ control subjects were heterozygous for this mutation. One former uranium miner died at the age of 72 years according to a gastric cancer. The adenocarcinoma of the stomach was progressive and metastasis could be found in skin, lung and muscles.

Extra pulmonary tumors due to ionising radiation have been reported (59). A statistically significant excess risk for cancers of the stomach was demonstrated in atomic bomb survivors. In a collaborative analysis of 11 studies in underground miners, statistically significant increases in mortality for cancers of the stomach were observed (61). The authors concluded that the increases in mortality from stomach cancers were unlikely to have been caused by radon, since they were unrelated to cumulative exposure. Also the risk of gastric cancer was assumed to be elevated in former uranium miners of SDAG Wismut (62). Bay et al (63) did not produce evidence for constitutional ATM mutations in breast or gastric cancer families. Nevertheless breast and gastric cancers appear to be the most frequent malignancies in A-T carriers and one ATM germ-line mutation has been described in a cancer family (63). However, further investigation did not reveal cosegregation of the A-T mutations with gastric cancer in the family (63).

In our study two $(4.0 \%)$ heterozygous ATM carriers for S49C mutation had Schneeberg lung cancer accepted as occupational disease. The odds ratio (OR) of the cumulative frequencies of this amino acid substitution between lung cancer patients $(n=48)$ and all other uranium miners without cancer $(n=160)$ was $\mathrm{OR}=6.63$ (95\% CI, 0.46-188.88). This difference was not significant at this low number of cases.

Carrier frequencies of any heterozygous ATM mutation, i.e., S707P, S49C or IVS10-6T $\rightarrow \mathrm{G}$, were observed at a higher rate in cancer patients $(8.0 \%)$ than in non-cancer controls $(1.88 \%)$. The elevated odds ratio $(\mathrm{OR}=4.55)$ may support an association of malignancies with heterozygosity for A-T mutations (22) but these preliminary findings need to be replicated in larger cohorts.

In the study of Kim et al (64) only one ATM genotype (IVS62160G $>$ A) showed an association with lung cancer risk. Subjects with the A allele at this site had a significantly higher risk of lung cancer than those with the $G$ allele $(\mathrm{OR}=1.6 ; 95 \% \mathrm{CI}, 1.1-2.1)$. However the allele frequencies of four loci $(24518 \mathrm{~A}>\mathrm{G}$, IVS21277C $>\mathrm{T}$, IVS61255T $>\mathrm{C}$ and IVS62160G $>A$ ) of the ATM gene in the Korean population were shown to be different from those of the SNP500Cancer database. In the study of Jialin et al (65) it was found that the genetic instability measured with the comet assay in lung cancer patients was significantly higher than that in the controls. On the contrary ATM protein expression levels in lung cancer patients were significantly lower than in controls. 
No strong correlation was found between ATM protein expression and ionizing radiation induced mean tail moment or micronucleus rate.

Further investigation is focusing on the identification of other ATM gene alterations in the wide spectrum of possible A-T mutations. The clinical impact and magnitude of the cancer risk in former uranium miners will need to be corroborated by studies screening high-risk populations with respect to lung cancer.

\section{References}

1. Kreuzer M, Brachner A, Lehmann F, Martignoni K, Wichmann H-E and Grosche B: Characteristics of the German uranium miners cohort study. Health Phys 83: 26-34, 2002.

2. Lehmann F, Hambeck L, Linkert K-H, Lutze H, Meyer H, Reiber H, Reinisch A, Renner H-J, Seifert T and Wolf F: Belastung durch ionisierende Strahlung im Uranerzbergbau der ehemaligen DDR. Schriftenreihe des Hauptverbandes der gewerblichen Berufsgenossenschaften, St. Augustin, 1998.

3. Bauer HD: Staubbelastungen in untertägigen Betrieben der ehemaligen Wismut während der Frühphase der Uranerzgewinnung nach dem 2. Weltkrieg. (Potential dust exposures in underground mines of the former Wismut Ltd. during early phase of uranium mining after the second world war). Gefahrstoffe Reinh Luft 57: 349-354, 1997.

4. Schuttmann W: Schneeberg lung diseases and uranium mining in the Saxon Ore mountains (Erzgebirge). Am J Ind Med 23: 355-368, 1993 .

5. Greenberg M and Selikoff IJ: Lung cancer in the Schneeberg mines: a reappraisal of the data reported by Harting and Hesse in 1879. Ann Occup Hyg 37: 5-14, 1993.

6. Butz M: Beruflich verursachte Krebserkrankungen. (Occupationally derived cancers) Schriftenreihe des Hauptverbandes der gewerblichen Berufsgenossenschaften, St. Augustin, 1996.

7. Brüske-Hohlfeld I, Möhner M and Wichmann HE: Predicted number of lung cancer cases in Germany among former uranium miners of the Wismut. Health Phys 72: 3-9, 1997.

8. Selig R: Erfahrungen zu Krebserkrankungen infolge 'WismutTätigkeit' und gutachterliche Gesichtspunkte. (Lung cancer following Wismut employment) Manuskript zum Vortrag auf dem IV. Karlshorster Kolloquim, Berlin, 29.5.1995.

9. Popp W, Plappert U, Müller WU, Rehn B, Schneider J, Braun A, Bauer PC, Vahrenholz C, Presek P, Brauksiepe A, Enderle G, Wüst T, Bruch J, Fliedner TM, Konietzko N, Streffer C, Woitowitz H-J and Norpoth K: Biomarkers of genetic damage and inflamation in blood and bronchoalveolar lavage fluid among former German uranium miners: a pilot study. Radiat Environ Biophys 39: 275-282, 2000.

10. Jorgensen TJ and Shiloh Y: The ATM gene and the radiobiology of ataxia-telangiectasia. Int J Radiol Biol 69: 527-537, 1996.

11. Shiloh Y: ATM and related protein kinases: safeguarding genome integrity. Nature Rev Cancer 3: 155-168, 2003.

12. Gatti RA, Boder E, Vinters HV, Sparkes RS, Norman A and Lange K: Ataxia-telangiectasia: an interdisciplinary approach to pathogenesis. Medicine 70: 99-117, 1991.

13. Sedgwick RP and Boder E: Ataxia-telangiectasia. In: Handbook of Clinical Neurology. Hereditary Neuropathies and Spinocerebellar Atrophies. De Jong J.M.B.V. (ed). Vol. 16, Chapter 26. Elsevier Science, Amsterdam, pp347-423, 1991.

14. Lavin MF and Shiloh Y: The genetic defect in ataxia-telangiectasia. Annu Rev Immunol 15: 177-222, 1997.

15. Rotman G and Shiloh Y: ATM: from gene to function. Hum Mol Genet 7: 1555-1563, 1998.

16. Taylor AMR, Metcalfe JA and McConville C: Increased radiosensitivity and the basic defect in ataxia-telangiectasia. Int J Radiat Biol 56: 677-684, 1989.

17. Thacker J: Cellular radiosensitivity in ataxia-telangiectasia. Int J Radiat Biol 66: S87-S96, 1994.

18. Meyn MS: Ataxia-telangiectasia and cellular response to DNA damage. Cancer Res 55: 5991-6001, 1995.

19. Beamish H, Williams R, Chen P and Lavin MF: Defect in multiple cell cycle check-points in ataxia-telangiectasia postirradiation. J Biol Chem 34: 20486-20493, 1996.
20. Baskaran R, Wood LD, Whitaker LL, Canman CE, Morgan SE, $\mathrm{Xu}$ Y, Barlow C, Baltimore D, Wynshaw-Boris A, Kastan MB and Wang JYJ: Ataxia-telangiectasia mutant protein activates c-Abl tyrosine kinase in response to ionizing radiation. Nature 387: 516-519, 1977

21. Swift M, Reitnauer PJ, Morell D and Chase CL: Breast and other cancers in families with ataxia-telangiectasia. New Engl J Med 316: 1289-1294, 1987.

22. Swift M, Chase CL and Morrell D: Cancer predispostion of ataxia-telangiectasia heterozygotes. Cancer Genet Cytogenet 46: 21-27, 1990

23. Athma P, Rappaport R and Swift M: Molecular genotyping shows that ataxia-telangiectasia heterozygotes are predisposed to breast cancer. Cancer Genet Cytogenet 92: 130-134, 1996.

24. Inskip HM, Kinlen LJ, Taylor AMR and Arlett CF: Risk of breast cancer and other cancers in heterozygotes for ataxiatelangiectasia. Br J Cancer 79: 1304-1307, 1999.

25. Olsen JH, Hahnemann MJ, Borresen-Dale A-L, BrondumNielsen K, Hammarström L, Kleinerman R, Kääriäinen H, Lönnqvist T, Sankila R, Seersholm N, Tretli S, Yuen J, Boice JD $\mathrm{Jr}$ and Tucker M: Cancer in patients with ataxia-telangiectasia and in their relatives in the Nordic countries. J Natl Cancer Inst 93: 121-127, 2001.

26. Swift M, Morell D, Massey RB and Chase CL: Incidence of cancer in 161 families affected by ataxia-telangiectasia. New Engl Med 325: 1831-1836, 1991 .

27. Gatti RA, Berkel I, Boder E, Braedt G, Charmley P, Concannon P, Ersoy F, Foroud T, Jaspers NGJ, Lange K, Lathrop GM, Leppert M, Nakamura Y, O'Connell P, Paterson M, Salser W, Sanal O, Silver J, Sparkes RS, Susi E, Wie S, White R and Yoder F: Localization of an ataxia-telangiectasia gene to chromosome 11q22-23. Nature 336: 577-580, 1988.

28. Uziel T, Savitsky K, Platzer M, Ziv Y, Helbitz T, Nehls M, Böhm T, Rosenthal A, Shiloh Y and Rotman G: Genomic organization of the ATM gene. Genomics 33: 317-320, 1996.

29. Platzer M, Rotman G, Bauer D, Uziel T, Savitsky K, BarShira A, Gilad S, Shiloh Y and Rosenthal A: Ataxiatelangiectasia locus: sequence analysis of $184 \mathrm{~kb}$ of human genomic DNA containing the entire ATM gene. Genome Res 7: 592-605, 1997.

30. Savitsky K, Bar SA, Gilad S, Rotman G, Ziv Y, Vanagaite L, Tagle DA, Smith S, Uziel T and Sfez S: A single ataxiatelangiectasia gene with a product similar to PI-3-kinase. Science 268: 1749-1753, 1995.

31. Zakian VA: ATM-related genes: what do they tell us about the function of human gene? Cell 82: 685-687, 1995.

32. Lakin ND, Weber P, Stankovic T, Rottinghaus ST, Taylor AMR and Jackson SP: Analysis of the ATM protein in wild-type and ataxia-telangiectasia cells. Oncogene 13: 2707-2716, 1996.

33. Chen G and Lee EY-HP: The product of the ATM gene is a 370-kDa nuclear phosphoprotein. J Biol Chem 271: 33693-33697, 1996.

34. Brown KD, Ziv Y, Sadanandan SN, Chessa L, Collins FS, Shiloh Y and Tagle DA: The ataxia-telangiectasia gene product, a constitutively expressed nuclear protein that is not up-regulated following genome damage. Proc Natl Acad Sci USA 94: 1840-1845, 1997.

35. Shafman T, Khanna KK, Kedar P, Spring K, Kozlov S, Yen T, Hobson K, Gatel M, Zhang N, Watters D, Egerton M, Shiloh Y, Kharbanda S, Kufe D and Lavin MF: Interaction between ATM protein and c-Abl in response to DNA damage. Nature 387: 520-523, 1997.

36. Kastan MB, Zhan Q, El-Deiry WS, Carrier F, Jacks T, Walsh WV, Plunkett BS, Vogelstein B and Fornace AJ: A mammalian cell cycle check-point pathway utilizing p53 and GADD45 is defective in ataxia-telangiectasia. Cell 71: 587-597, 1992.

37. Lu X and Lane DP: Differential induction of transcriptionally active p53 following UV or ionizing radiation: defects in chromosome instability syndromes? Cell 75: 765-778, 1993.

38. Kastan MB and Lim DS: The many substrates and functions of ATM. Nature Rev Mol Cell Biol 1: 179-186, 2000.

39. Baumer A, Bernthaler U, Wolz W, Hoehn H and Schindler D: New mutations in the ataxia-telangiectasia gene. Hum Genet 98: 246-249, 1996.

40. Byrd PJ, McConville CM, Cooper P, Parkhill J, Stankovic T, McGuire GM, Thick JA and Taylor AMR: Mutations revealed by sequencing the 5 ' half of the gene for ataxia-telangiectasia. Hum Mol Genet 5: 145-149, 1996. 
41. Gilad S, Khosravi R, Shkedy D, Uziel T, Ziv Y, Savitsky K, Rotman G, Smith S, Chessa L, Joregensen TJ, Harnik R, Frydman M, Sanal O, Portnoi S, Goldwicz Z, Jaspers NGJ, Gatti RA, Lenoir G, Lavin MF, Tatsumi K, Wegener R-D, Shiloh Y and Bar-Shira A: Predominance of null mutations in ataxia-telangiectasia. Hum Mol Genet 5: 433-439, 1996.

42. Telatar M, Wang Z, Udar N, Liang T, BernatowskiaMatuskiewicz E, Lavin M, Shiloh Y, Concannon P, Good RA and Gatti R: Ataxia-telangiectasia: mutations in ATM cDNA detected by protein-truncation screening. Am J Hum Genet 59: 40-44, 1996.

43. Vorechovsky I, Luo L, Prudente S, Chessa L, Russo G, Kanariou M, James M, Negrini M, Webster ADB and Hammarström L: Exon-scanning mutation analysis of the ATM gene in patients with ataxia-telangiectasia. Eur J Hum Genet 4: 352-355, 1996.

44. McConville CM, Stankovic T, Byrd PJ, McGuire GM, Yao Q-Y, Lennox GG and Taylor AMR: Mutations associated with variant phenotypes in ataxia-telangiectasia. Am J Hum Genet 59: 320-330, 1996.

45. Gilad S, Khosravi R, Harnik R, Ziv Y, Shkedy D, Galanty Y, Frydman M, Levi J, Sanal O, Chessa L, Smeets D, Shiloh Y and Bar-Shira A: Identification of ATM mutations using extended RT-PCR and restriction endonuclease fingerprinting and elucidation of the repertoire of AT mutations in Israel. Hum Mutat 11: 69-75, 1998.

46. Telatar M, Teraoka S, Wang Z, Chun HH, Liang T, Castellvi-Bel S, Udar N, Borresen-Dale A-L, Chessa L, Bernatowska-Matuskiewicz E, Porras O, Watanabe M, Junker A, Concannon P and Gatti R: Ataxia-telangiectasia: identification and detection of founder-effect mutations in the ATM gene in ethnic populations. Am J Hum Genet 62: 86-97, 1998.

47. Stankovic T, Kidd AMJ, Sutcliffe A, McGuire GM, Robinson P, Weber P, Bedenham T, Bradwell AR, Easton DF, Lennox GG, Haites N, Byrd PJ and Taylor AMR: ATM mutations and phenotypes in ataxia-telangiectasia families in the British Isles: expression of mutant ATM and the risk of leukemia, lymphoma and breast cancer. Am J Hum Genet 62: 334-345, 1998.

48. Sandoval N, Platzer M, Rosenthal A, Dörk T, Bendix R, Skawran B, Stuhrmann M, Wegner R-D, Sperling K, Banin S, Shiloh Y, Baumer A, Bernthaler U, Sennefelder H, Brohm M, Weber BHF and Schindler D: Characterisation of ATM gene mutations in 66 ataxia-telangiectasia families. Hum Mol Genet 8: 69-79, 1999

49. Eigenwillig GG: Berufliche Strahlenexposition durch Radon und dessen Folgeprodukte. Konsequenzen für die Anerkennung als Berufskrankheit. Dt Ärzteblatt 94: 1057-1062, 1997.

50. Dörk T, Bendix R, Bremer M, Rades D, Klöpper K, Nicke M, Skawran B, Hector A, Yamini P, Steinmann D, Weise S, Stuhrmann $M$ and Karstens JH: Spectrum of ATM gene mutations in a hospital-based series of unselected breast cancer patients. Cancer Res 61: 7608-7615, 2001.

51. Newton CR, Graham A, Heptinstall LE, Powell SJ, Summers C, Kalsheker N, Smith JC and Markham AF: Analysis of any point mutation in DNA. The amplification refractory mutation system (ARMS). Nucl Acids Res 17: 2503-2516, 1989.

52. Broeks A, Urbanus J, De Knijff P, Devilee P, Nicke M, Klöpper K, Dörk T, Floore A and van't Veer L: IVS10-6T >G, an ancient ATM germline mutation linked with breast cancer. Hum Mutat 2: 521-528, 2003.

53. Smith AH, Lopipero PA and Barroga VR: Meta-analysis of studies of lung cancer among silicosis. Epidemiology 6: 617-624, 1995.
54. Tsuda T, Babazone A, Yamamoto E, Miuo Y and Matsnoka H: A meta-analysis on the relationship between pneumoconiosis and lung cancer. J Occup Health 39: 285-294, 1997.

55. Teraoka SN, Malone KE, Doody DR, Suter NM, Ostrander EA, Daling JR and Concannon P: Increased frequency of ATM mutations in breast carcinoma patients with early onset disease and positive family history. Cancer 92: 479-487, 2001.

56. Geoffroy-Perez B, Janin N, Ossian K, Lauge A, Croquette M-F, Griscelli C, Debre M, Bressac-de-Paillerets B, Aurias A, Stoppa-Lyonnet D and Andrieu N: Cancer risk in heterozygotes for ataxia-telangiectasia. Int J Cancer 93: 288-293, 2001.

57. Inskip H, Beral V, Fraser P, Booth M, Coleman D and Brown A: Further assessment of the effects of occupational radiation exposure in the United Kingdom atomic energy authority mortality study. Br J Ind Med 44: 149-160, 1987.

58. Beral V, Inskip H, Fraser P, Booth M, Coleman D and Rose G: Mortality of employees of the United Kingdom atomic energy authority, 1946-1979. Br Med J 17: 440-447, 1985.

59. Thompson DE, Mabuchi K, Ron E, Soda M, Tokunaga M, Ochikubo S, Sugimoto S, Ikeda T, Terasaki M and Izumi S: Cancer incidence in atomic bomb survivors. Part II: solid tumors, 1958-1987. Radiat Res 137: S17-S67, 1994.

60. Hall EJ, Schiff PB, Hanks GE, Brenner DJ, Russo J, Chen J, Sawant $G$ and Pandita TK: A preliminary report: frequency of A-T heterozygotes among prostate cancer patients with severe late responses to radiation therapy. Cancer J Sci Am 5: 385-389, 1998.

61. Darby SC, Whitley E, Howe GR, Hutchigs SJ, Kusiak RA, Lubin JH, Morrison HI, Tirmarche L and Radford EP: Radon and cancers other than lung cancer in underground miners: a collaborative analysis of 11 studies. J Nat Cancer Inst 87: 378-384, 1995.

62. Jacobi W and Roth P: Risiko und VerursachungsWahrscheinlichkeit von extrapulmonalen Krebserkrankungen durch die berufliche Strahlenexposition von Beschäftigten der ehemaligen Wismut AG. GSF-Forschungszentrum für Umwelt und Gesundheit, Institut für Strahlenschutz, Neuherberg, 1995 .

63. Bay JO, Grancho M, Pernin D, Presneau N, Rio P, Tchirkov A, Uhrhammer N, Verrelle P, Gatti RA and Bignon YJ: No evidence for constitutional ATM mutation in breast/gastric cancer families. Int J Oncol 12: 1385-1390, 1998

64. Kim JH, Kim H, Lee KJ, Choe KH, Ryu JS, Yoon HI, Sung SW, Yoo KY and Hong YC: Genetic polymorphisms of ataxiatelangiectasia mutated affect lung cancer risk. Human Mol Gen 15: 1181-1186, 2006.

65. Jialin L, Jiliang H, Lifen J, Wei Z, Zhijian C, Shijie C and Shijie X: Variation of ATM protein expression in response to irradiation of lymphocytes in lung cancer patients and controls. Toxicology 224: 138-146, 2006.

66. Beaudet AL and Tsui L-AC: A suggested nomenclature for designating mutations. Hum Mut 2: 245-248, 1993.

67. Savitsky K, Sfez S, Tagle DA, Ziv Y, Sartiel A, Collins FS, Shiloh Y and Rotman G: The complete sequence of the coding region of the ATM gene reveals similarity to cell cycle regulators in different species. Hum Mol Genet 4: 2025-2032, 1995.

68. International Labour Office (ILO): Guidelines for the use of ILO International Classification of Radiographs of Pneumoconioses. Rev. ed. Occupational Safety and health Services, Geneva, no. 22 (rev.), 1980. 